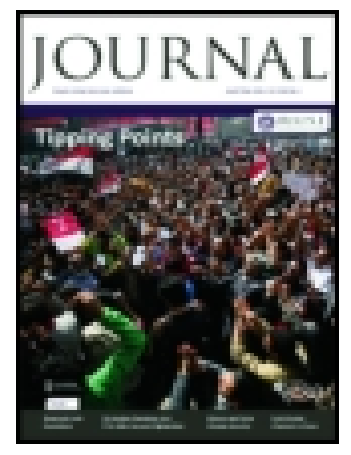

Royal United Services Institution. Journal

\title{
The Flight of Projectiles, Together with the Description of an Instrument Constructed by him to Show the Trajectory of a Ball from a Given Elevation and Range, Together with its Initial Velocity and Force of Striking
}

\author{
Major-General Anstruther Late C.B. \& Major-General J. T. Boileau R.E., F.R.S.
}

To cite this article: Major-General Anstruther Late C.B. \& Major-General J. T. Boileau R.E., F.R.S. (1865) The Flight of Projectiles, Together with the Description of an Instrument Constructed by him to Show the Trajectory of a Ball from a Given Elevation and Range, Together with its Initial Velocity and Force of Striking, Royal United Services Institution. Journal, 9:37, 372-394, DOI: 10.1080/03071846509434763

To link to this article: http://dx.doi.org/10.1080/03071846509434763

Published online: 11 Sep 2009.

Submit your article to this journal $\pi$

山 Article views: 3

View related articles 


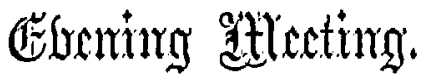

Monday, July 10th, 1865.

Captain E. GaRdiner fisibouRne, R.N., C.B., in the Chair.

NAMIES of AIEATERS who joined the Institution between Jume 5th and July 10th.

ANNUAL.

Heathorn, T. B., Capt. R.A. 11.

Berkeley, Geo. S., Capt. R.E. 11.

Man, Jno. Alex., Lieut. Rogal Aberdecnshire Highlanders Militia. $1 l$.

Bedford, G. A., Capt. R.N. 12.

Curtis, A. C., Lieut. R.N. 11 .

England, WV. G., Lieut. R.N. 11.

Fletcher, Alex., Capt. 12th Rogal Iancers. 12.

Fandeleur, C. T. B., Iicut, 12klı Rogal Lancers.

Thompson, G. A., Comet 12th Rojal Iancers. 11.

Burhinjoung, II. II., Comet 12th Rojal Lancers. 11.

Arundell, Hon. I. I. J., Cornet 12th Rogal Lancers.

Cockle, Geo. MI. A., Capt. Royal Westmoreland Mil.

Davis, Hugh, Lieut. R.N. 1 .
Castle, E. J., Licut. R.E. $1 l$.

Smith, W. II. C., Lieut. 101th Bengal Fusiliers. 11.

Kennedy, G. MI., Licut. R.A. 11 .

Lamrence, Geo. St. Patrick, Major-Gen., C.B., Beng. Staff Corps. $1 l$.

Barstow, T. 1 . A., Ens. Fand Highrs.

Greenhill, J. G., Asst.-Surg. 72nd Highrs.

Iraughton, T., Licut. R.A. 11.

Willoughby, M. F., Major-Gen., C.B., ret. Bom. Army. 11.

Tauglan, II. B.; Capt. 1st Batt. 20th Regt. 11 .

Dobie, W. A., Capt. 12th Royal Lancers. 11 .

Buttanslaw, W. II., Pagmastcr, 12th Rojal Lanecrs. $1 l$.

FitzRoy, Rob. O.B., Licut. R.r. 1 .

THE FLIGIT OF PROJECTILES, TOGETIER TVITH THE DESCRIPTION OF AN INSTRUMIENT CONSTRUCTED BY HIM TO SHOT THE TRAJECTORY OF $\Lambda$ BALL FROMI $\Lambda$ GIVEN ELEVATION AND RANGE, TOGETIIER IVITII ITS INITIAL VELOCITY AND FORCE OF STRIKING.

A Paper prepared by Major-General Axstrutien, C.B., late Madras Artillery, and read by MIajor-GenernI J. T. BoILEAd, R.E., F.R.S.

Prefice.

Extract from "Straith's Memoir of Lrtillery," pp. 81, 82.

"Dr. Gregorer, in his lectures upon gunnery, observes on the differ" ence between the times employed by a ball in ascending and des- 


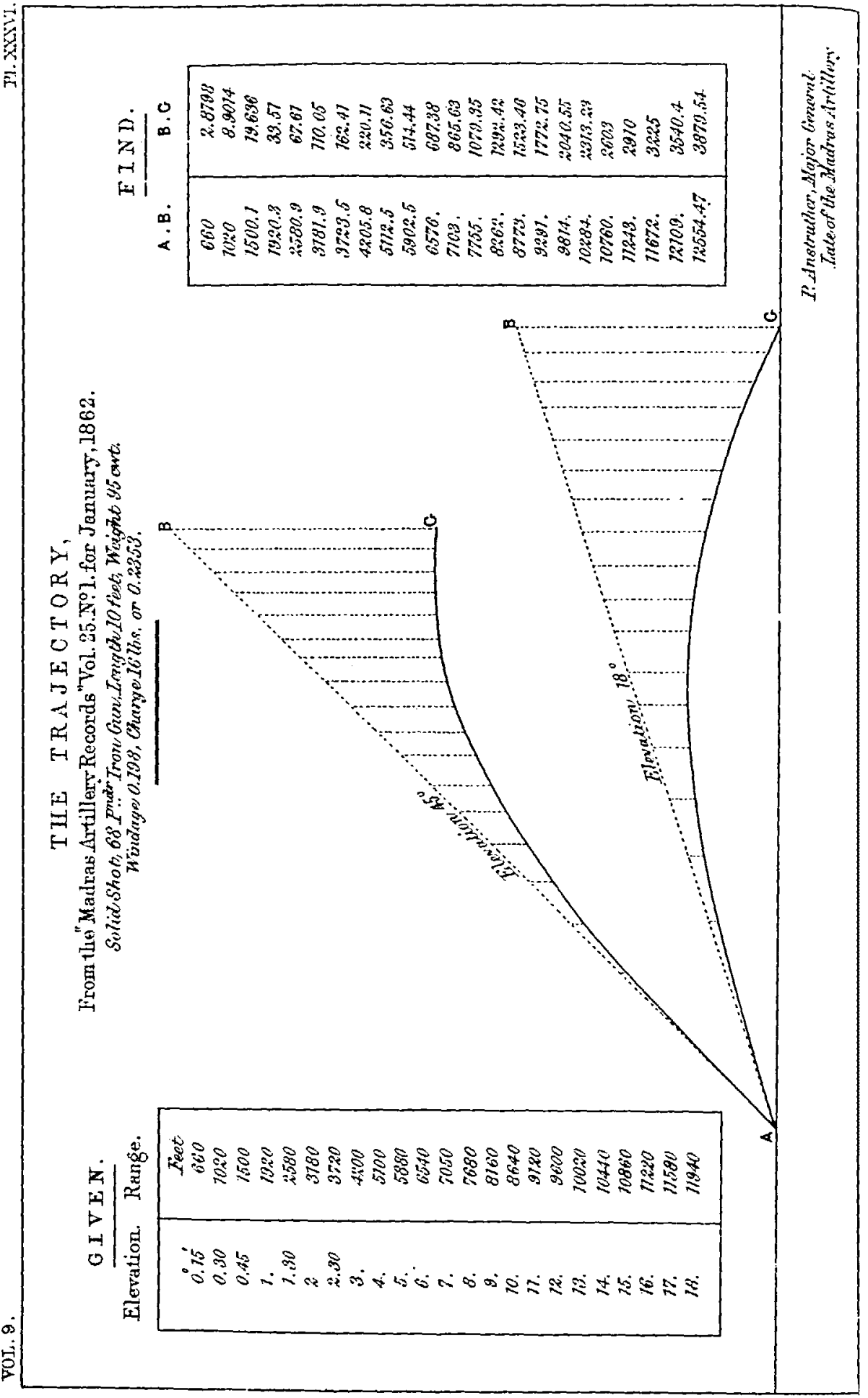


" cending vertically through the same space. If a 24 -pound iron ball "were projected vertically uprrards, with a velocity of 2,000 feet per " second, it would ascencl to the height of $6,42 \pm$ feet before its upward " motion was extinguished, and it would pass over that space in less "than $9 \frac{1}{2}$ seconds. (This is computed in Hutton's Mathematics, rol. 3.) "It might, on a cursory view of the subject, be supposed that the "circumstance of the descent would be analogous to those of the " ascent, but in an inverted order; and so they would, in a non"resisting medium, but in the air the case is rridely different. After " the ball had descended 2,700 feet, the resistance of the air would be " equal to the weight of the ball, there would remain no farther cause " of acceleration, and the ball would descend uniformly with its "terminal velocity (that is, the greatest velocity which a heary body "can acquire when falling in the air), which does not exceed 419 feet "per second. It would require, therefore, $\frac{6424-2700}{119}$ or 6 seconds, to " descend the remaining 3,724 feet, in addition to the time, about 10 "seconds, which had been occupied in descending through the first " 2,700 feet; so that, in this instance the time of descent rould bo "about double that of ascent. In all cases where the projectile " velocity exceeds 300 or 400 feet, the time of descent will exceed "that of ascent; and their difference is greater the more the initinl "velocity exceeds that limit."

\section{Sectiox I.}

The preface shows what was taught at our artillery acndemics of Woolwich and Addiscombe as the science of gunnery. Wre read that a ball, fired vertically upwards with a velocity of 2,000 feet per second, would ascend during a time "less than 9t scconds," after which, all its upward motion being extinguished, it would descend during "about" 16 seconds, thus making a total time of flight of only 25 seconds, or less, for this most enormous relocity at the greatest possible elevation. Tet almost every table of recorded practice shows very considerably longer time of hight, obtained at elevations much less than $90^{\circ}$, by the use of moderate charges, therefore with no great relocities. The concluding passage tells us that "in this instance the time of descent would be about double that of ascent. In all cases uthere the projectile velocity exceeds 300 or 400 feet, the time of descent will exceed that of ascent." These words inculcate a principle so crroneous that it is impossible to calculate the flight of any projectilo until this mistake has been corrected.

\section{Secrios II.}

Whatever the elevation, whaterer the velocity, it is impossible that the time of the descent of any ball fired upwards, can be either greater or less than at the time of its ascent, or can be greater or less than the whole time of flight. For, the descent is the motion which is produced by the force of gravity, and this force acts upon the ball from the very moment of its being set in motion, and continues to act upon it during 
the whole time of its flight. The second law of motion, rightly understood, teaches this: it tells us that tho motion which is produced by the force of gravity acting upon the ball whilst in motion upwards is the same, both in magnitude and direction, as that motion which would be produced in the same time, by tho same force, if it were acting upon the same ball suffered to fall freely from a state of rest. Whatever the eleration, whatever the relocity, the ascent and descent of any ball forced upwards must be of equal duration. These two motions may differ in magnitude, and must differ in direction, but they cannot differ in duration; they are simultaneous and not successive; they are synchronous, not consecutive. Hence it follows that if we know the descent wo can calculate the ascent; we can graduate the line representing the ascending motion, measuring the initial velocity, and determining the trajectory for that relocity at any eleration whatever. This constitutes the whole science of gunnery.

\section{Sectrox III.}

There are three forces acting upon every ball throughout its flight:

I. The projectile force.

II. The force of gravity.

III. The resistance of the atmosphere.

Of these threo the first and the second produce motions which we shall take into consideration separately. The third force produces no motion, lut acts by reducing the magnitude of the motions produced by the other two forces. Thus, although there aro three forces acting, there are only two motions produced, and we have only to componnd the motion which is produced by the force of gravity during the flight of the ball with that motion which is produced by the projectile force during the same time, to obtain the actual motion of the ball, its true trajectory, or path through the air.

\section{Section IV.}

By supposing the angle of elevation to be $90^{\circ}$ we throw upon one single vertical line the two motions which we seek to compound, we thius conccal from our own viow the fact of their distinct and separate simultancous existence. We make each of them in succession cover, and so hide, the othcr. But, by supposing any other elevation, we shall be enabled to employ as a diagram a right-angled triangle, in which the oblique and vertical sides shall represent the two motions which we are to compound, visibly separate and distinct from each other; then, if we can determine the graduation for time of the entire magnitude of each of these two straight lines, we shall be able to draw the true trajectory for any elevation whatever to any degree of minute accuracy that may be desired.

Galileo showed how this was to be done; he proved that the flight of a ball, projected obliquely, must be in the curre of a parabola, "unless so far as it uould be diverted from that track by the resistance of 
the air." But IIutton, followed by Gregory and Straith, taught that the descent commences when the ascent censes. If this were the case, the motions of every ball would be rectilinear, its angle of descent nust always be a right angle, which would render any secoud graze an impossibility, and "ricochet" a word without meaning.

\section{Sectron V.}

Let $\Lambda \mathrm{B}$ G, Fig. 1 , be a right-angled triangle, within which we are to inscribe the trajectory of a ball, which being fired from $A$ towards $B$ strikes $G$ at the expiration of the time of flight, let us suppose 25.5 seconds, then

I. A $B$ represents the motion produced by the projectile force in $25 \cdot 5$

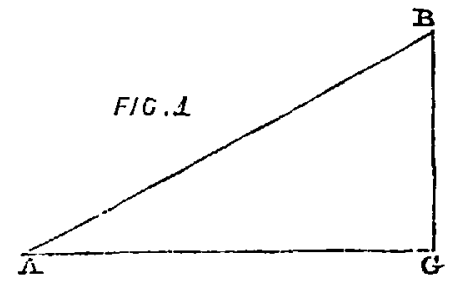
seconds.

II. B G represents the motion produced by the force of gravity in $25 \cdot 5$ seconds.

III. $A \mathrm{G}$ represents the ground over which $\Lambda \mathrm{B}$ extends.

The curvo described by the ball in going from $A$ to $G$ is usually defined by giving the abscissa and ordinates, the abscissa being the graduation of $A G$, and the ordinates, perpendiculars showing the height attained, these are the "internal," measurements of the curve. By this method we require to alter every figure of the calculation for every change of elevation, the consequence is that no one has ever rentured to draw a trajectory for any service relocity with service charge. But if artillerists would define the curre by its "external" measurements, by the graduation of the two lines $A$ B and B G, they would find their advantage in this, that one calculation will serve for all elevations, and that the first space in the graduation of $A B$ denotes the initial relocity at once.

The graduation of $A B$ can only be determined from that of $B G$ which therefore we shall now find.

\section{Section VI.}

The vertical, $\mathrm{B} \mathrm{G}$, is the measure of the fall by gravity in $25 \cdot 5$ seconds of time, we are to find its magnitude and graduation. The fall by gravity in any time, $t$, is equal to $t^{2} \times \frac{1}{2} g$, where the letter $g$ expresses the velocity which would result from a fall of one second's duration, in a vacuum. The value of $g$ varies slightly according to the latitude of the place, but we shall consider its value, in a vacuum, to be $32 \cdot 2$ feet. The resistance of the atmosphere very greatly alters the value of $g$, but we have no difficulty whatever in determining the extent of this alteration of value, for thirty seconds or more, and we only require a fer experiments, ensily made, to raise this to sixty or seventy seconds.

We have a very great number of experiments recorded, in which 
the range, eleration, and time of flight are given; we multiply the given range by the tangent of the given eleration; the product is the measure of the fall by gravity in the giren time of flight. A careful comparison of visy many rccorded ranges, Sc., led the present writer to adopt the following. scale of value for the letter $g$, and it was offered to the world in a lecture delivered at the Royal United Service Institution in the summer of 1861.

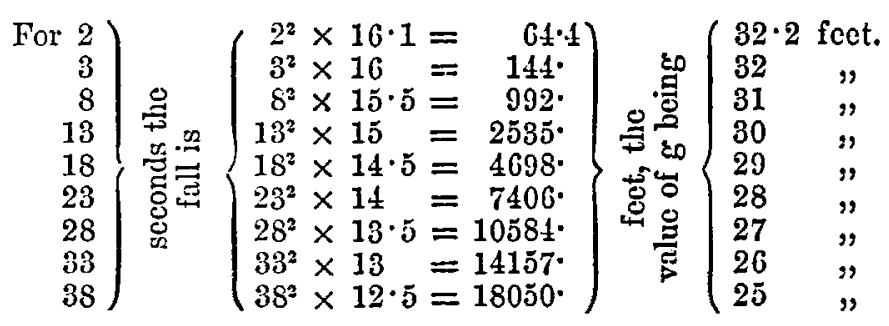

The latter line being uncertain.

The Ordnance Select Committee may be said to hare approred and confirmed the principle of the foregoing, as they did, in the winter of 1862 , denounce as erroneous the belicf which they ascribed to the present writer, that is, a belief that "the value of $g$, expressing the fall " of an object in the atmosphere under the attraction of gravity, is inca"riable-altcays $32 \cdot 16$ feet."

The latest experiment of which we hare any record, the firing at Shoeburyness, on the 20th of July, 1864, shows that we are not far wrong, if not perfectly right. The cleration mas $23^{\circ} . .9^{\prime}$, and the range 7,300 yards or 21,900 feet. Here the tangent of $23^{\circ} .09^{\prime} . .00^{\prime \prime}$, multiplied by 21900 , gives $9363 \cdot 74$ feet, as the measure of the fall by gravity, from which we deduce the time of flight.

We are to determine the time in which a ball will fall through the space of 9363-7392 fect, and we see by a glance at the above table that it is between 23 seconds and 28 seconds; we try 26 seconds and 27 seconds, and we then try $26^{\circ} 1$ scconds, and $26^{\circ} \cdot 2$ seconds, which we find to give as follows, viz:-

$$
\begin{aligned}
& 26 \cdot 1^{2} \times 13 \cdot 69=9325 \cdot 7619 \text { feet, } 37 \cdot 9743 \text { feet, short } \\
& 26 \cdot 2^{2} \times 13 \cdot 68=9390 \cdot 4992 \text { feet, } 26 \cdot 76 \text { feet, orer. }
\end{aligned}
$$

Lastly, we try $26.16^{2} \times 13.684=9364.5852$ fect, which is only 0.846 fect too long, and this we say is the time of flight for a range of 7,300 yards at an clevation of $23^{\circ} . .9^{\prime} . .00^{\prime \prime}$, Now the "Times" tells us that the observed time was $26 \cdot 2$ seconds, which is 0.04 second more than we should expect, but this suffices to show that the above table is true in principle, and nearly true in fact. The fall for 25.5 seconds of time, by this rule, would be $25 \cdot 5^{2} \times 13 \cdot 75^{2}=8940 \cdot 9375$ feet, and this we accept as the magnitude of B G in Fig. 1 . 


\section{Sectrox VII.}

Knowing the magnitude of $B \mathrm{G}$ and its graduation for time, we can deduce the magnitude of $A$ B for any named angle of elevation, and we shall show how to determine the graduation of $A B$ when its magnitude is known. For convenience of comparison with the tables given in our books, we shall suppose the eleration $45^{\circ}$, and proceed to work out the trajectory from these two data, the elevation, $45^{\circ}$, and the time of flight, $25 \cdot 5$ seconds.

Let $A B$ G, Fig. 2, be a right angled triangle in which the angle $B A G$ is the given elevation, $45^{\circ}$, and the side $\mathrm{B} \mathrm{G}$ is the fall by gravity for $25 \cdot 5$ seconds, 8940.9375 feet, then wo find $A \mathrm{G}=\mathrm{B} \mathrm{G}$, and $A B=\Lambda$ G $\sqrt{2}=8940.9375$ 종 $=126.44 .395$ feet. Draw $A \mathrm{Y}$, parallel to, and equal to, $B \mathrm{G}$, and join $B \mathrm{Y}$, then is $A \mathrm{G} \mathrm{B} \mathrm{Y} \mathrm{a} \mathrm{parallelogram,} \mathrm{of} \mathrm{which}$ $A B$ is the dingonal, and we add to the definitions given in section $\mathrm{V}$, this new one, IV, A Y represents the vertical height attained by $\perp B$.

We know, from the law of the com-

FIG. 2.

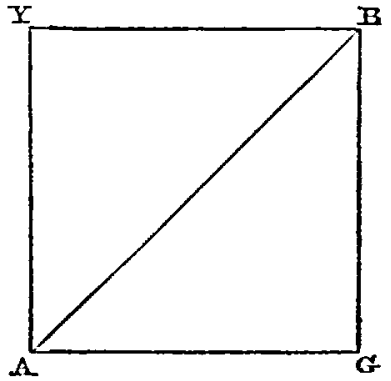
position and re-solution of forces, that the force which produces the motion represented by the line $A B$, is the resultant or equiralent of two forces producing motions represented, both in magnitude and direction, by the two sides $A Y, A G$, of the parallelogram $A G B Y$ of which said $\perp B$ is the diagonal. Therefore it is absolutely certain-

First. That the duration of the motion represented by $A \mathrm{~B}$, the time during which the projectile force is acting upon the ball, to drive it from $\Lambda$ in a direction parallel to $A \mathrm{~B}$, cannot possibly be greater than, or less than, the duration of either of the two forces of which it is compounded.

Secondly. That it is impossible that the durntion of either one of the two $f(r c e s$ of which the force producing $A \mathrm{~B}$ is compounded can be either greater than, or less than, the duration of the other of the two.

If we can, therefore, determine the graduation of the rertical ascent $\Lambda \mathrm{Y}$, we shall be enabled to deduce the graduation of $\Lambda \mathrm{B}$, which is the only thing required to enable us to draw the trajectory of the ball.

\section{Section VIII.}

We have to determine the graduation of the rertical ascent $\Lambda \mathrm{Y}$, of which we know the magnitude and the duration. Both in magnitude and duration this motion is exactly equal to the motion represented by the line $B \mathrm{G}$, but the graduation of the descent is invariable, it has 
been given in table on page 376, wherens the graduation of the ascent, $A Y_{L}$ varies with the angle of elevation. When the angle of elevation is $90^{\circ}$, when the ball is fired vertically upwards, supposing such a thing possible, then, and only then, would the graduation of ascent be exactly that of the descent, but in an inverted order, and we give in Table $A$, the graduation of each of the tro motiuns, in juxtaposition, with a column, to show, by the differences between the two, the actual height attained by the ball.

Wn extract the following from the lecture alluded to abore :- "If we : deduct the fall for $25 \cdot 40$ seconds from that for 25.50 , the difference " will give the space described by the ball in the last hundredth part " of a second of its fall. It is as follows, viz. :-

$$
\begin{aligned}
& \text { " } 25 \cdot 50 \text { seconds, } 25 \cdot 50^{2} \times 13 \cdot 750=8940 \cdot 9375 \\
& \text { " } 29 \cdot 49 \text { " } 25 \cdot 40^{2} \times 13 \cdot 751=8931.5761151 \\
& \text { " a difference of } 0 \cdot 01 \text { second, and } 6 \cdot \mathbf{6 6 1 3 8 4 9} \text { feet, showing a } \\
& \text { " velocity of }
\end{aligned}
$$

The difference between our calculation and that of Hutton is as follows :- Ile gives the relocity as 2,000 feet per second; we say it is $636.128 \mathrm{~s}$ feet; he gives an actunl ascent of 6,424 feet; we say it is 4,056 feet; he divides the time of flight into tro unequal parts; we say the tro motions are simultaneous.

We hare said before, that the graduation of $A Y$, the rertical ascent, varies with the angle of eleration, we shall now show to what nin extent this is the case. Suppose the ball fired at elevation to give $1 \frac{1}{2}$ seconds time of flight, initial velocity $636 \cdot 1385$ feet per second. $W_{c}$ find the elevation thus, say-

as the oblique ascent for 1.5 seconds, 034.5375 feet, $:$ is to, $90^{\circ}$,

: : so is the rertical descent, for 1.5 scconds, 36.3375 feet, : the angle of elevation, $2^{\circ} . .13 .40, \operatorname{logm} .8 \cdot 58975836$.

Wre obtain the graduation of the vertical ascent by saying as $90^{\circ}$

$$
:\left\{\begin{array}{l}
315 \cdot 9375 \\
311 \cdot 5375 \\
307 \cdot 0625 \\
\frac{931 \cdot 5357}{3}
\end{array}\right\}:: 2^{\circ} . .13 . .40:\left\{\begin{array}{l}
12 \cdot 284558 \\
12 \cdot 113471 \\
11 \cdot 939471 \\
36 \cdot 3375
\end{array}\right.
$$

The vertical ascent and rertical descent, equal in magnitude and duration, differ very widely in graduation at this low elevation, as the following table will show:-

In each half-second $12 \cdot 281558$ and the descent is $4 \cdot 0625$

the ascent is

$12 \cdot 113471$

11.939471

$12 \cdot 12^{7} 5$

$20 \cdot 1$

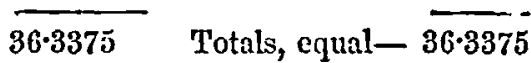

Table B, Appendix, shows how to apply table $\Lambda$ to any other eleration, less than $90^{\circ}$, drawing the trajectory without any further trouble 
in calculating; let it be supposed that the elevntion desired is $35^{\circ}$, we draw a right-angled triangle, its angles $90^{\circ}, 35^{\circ}$, and $55^{\circ}$, and on the hypothenuse we lay off the 36 graduations marked as "Ascent Feet" in table B, then let fall 36 perpendiculars showing the "Descent Feet" in the same table; then a line joining the lower extremities of all these perpendiculars is the real trajectory or path of the ball.

Before leaving this velocity we shall show its range at $45^{\circ}$ eleration. We find, by repeated trials, that the time of flight will be $20 \cdot 025$ seconds, for the ascent in 20.625 seconds is as follows, riz. :-

$$
\text { From } 25 \cdot 5^{2} \times 13.75=8940 \cdot 9375 \text { the possible ascent for this }
$$

Take $4 \cdot 875^{2} \times 15 \cdot 8125=375 \cdot 7939 \pm 23125$ the fall in $4 \cdot 875$ seconds, then

$20 \cdot 625$ seconds time, $8505 \cdot 1435 \pm 6875$ is the ascent for this time and $20.625^{2} \times 14 \cdot 2375=6056.5$ feet, the deseent in tho same time. Then wo say as $9565 \cdot 14355: 90: 60565: 45^{\circ}$ the elevation; so that the range at $45^{\circ}$ for this velocity is 6056.5 feet, or 2019 yards. We have already shown that the initial velocity for 25.5 seconds vertical flight is $636 \cdot 1285$ feet per second; wo shall now show the relocity for the same time of flight at elevation $45^{\circ}$; it is worked out in the Appendix C. Fired with elevation $45^{\circ}$, if the vertical descent is 8910.0375 feet, the obliquo ascent must bo $8940.9375 \quad \sqrt{2}=12644 \cdot 1$ feet. We find that the relocity to give an ascent of 12614.4 fect in $25 \cdot 5$ seconds is $733 \cdot 3$ feet per second.

In the Appendix, table $\mathrm{D}$, we give a table showing 32 ranges for this velocity. Any artillerist can now draw the trajectory as described in the last para. on page 378 , or he may employ such an instrument as I have now the honour to show, a description of which is given in Appendix $F$. It is humiliating to think that no book in the English language gives us one service range for elevation, with the initial velocity of the ball. 'The French are far in adrance of us in this respect; their book, the "Aide-MIémoire à l'usage des Officiers d'Artillerie," gives, at p. 431, no less than 30 recorded ranges at $45^{\circ}$, with the initial relocity of the ball for each one. In the Appendix $E$, will be found the calculation by which our theory would assign an initial velocity of $777 \cdot 1$ feet, or 236.8 metres to tho ball, which at $45^{\circ}$ ranged $3566^{\circ} .1$ yards, or 3261 metres. This velocity the French Aide-Mémoire says was really 239 metres, being only $2 \cdot 137$ metres more than we make it. Our theory, therefore, agrees moderately well with that of the French artillerists, judging from results. IIow widely it differs from that of WVoolwich and Addiscombe, as taught by IIutton, has been shown in section VIII (quod vide). Our greatest want now, is a well-recorded table of times of flight, exceeding 40 or 50 seconds. We have nothing beyond 31 seconds in our books, nor have the French. In the Appendix G, will be found the calculations of the trajectory of a ball wlich, at $30^{\circ}$ clevation, ranged 4850 yards. This ball, at $45^{\circ}$ elevation, would range 14,000 feet in $32 \cdot 79$ seconds. According to our theory, if fired vertically upwards, it would not return to the ground until the expiration of 41.58 seconds, its initial velocity being 836.8 feet per second. 
The model which I now place before you, will prore to any gentle. man, that if ho will obtain a true table of ranges for elevation and obserred time of flight, he can construct an instrument which slanl answer all possible questions on gunnery, and render that science as easy and simple as the first rules of arithmetic. My own instrument may not be true, becatse I have not got a table of ranges that can be depended upon, and I am denied the means of obtaining one. 
TABre A.

Time of Flight 25.5 Scconds. Initial Velocit5, 63613.85 fect per Secoud.

\begin{tabular}{|c|c|c|c|c|c|}
\hline \multirow{2}{*}{$\begin{array}{c}\text { Seconds } \\
\text { of } \\
\text { Time. }\end{array}$} & \multicolumn{2}{|c|}{ Tertical Ascent (in feet). } & \multirow{2}{*}{$\begin{array}{l}\text { Fall by } \\
\text { Gravity, in } \\
\text { fect. }\end{array}$} & \multirow{2}{*}{$\begin{array}{c}\text { Actual } \\
\text { Height at- } \\
\text { tained in tho } \\
\text { whole time. }\end{array}$} & \multirow{2}{*}{$\begin{array}{l}\text { Space passed } \\
\text { through in } \\
\text { cach } \frac{2}{2} \\
\text { sccond. }\end{array}$} \\
\hline & Gradual. & Cuimulatirc. & & & \\
\hline $\begin{array}{l}0 \cdot 5 \\
1 \\
1 \cdot 5 \\
2 \\
2 \cdot 5 \\
3 \\
3 \cdot 5 \\
4 \\
4 \cdot 5 \\
5 \\
5 \cdot 5 \\
6 \\
6 \cdot 5 \\
7 \\
7 \cdot 5 \\
8 \\
8 \cdot 5 \\
9 \\
9 \cdot 5 \\
10 \\
10 \cdot 5 \\
11 \\
11 \cdot 5 \\
12 \\
12 \cdot 5 \\
12 \cdot 75 \\
13 \\
13 \cdot 5 \\
1.4 \\
14 \cdot 5 \\
15 \\
15 \cdot 5 \\
16 \\
16 \cdot 5 \\
17 \\
17 \cdot 5 \\
18 \\
18 \cdot 5 \\
10 \\
10 \cdot 5 \\
20 \\
20 \cdot 5 \\
21 \\
21 \cdot 5 \\
22 \\
22 \cdot 5 \\
23 \\
23 \cdot 5 \\
2.5 \\
21 \cdot 5 \\
25 \\
\end{array}$ & $\begin{array}{c}315 \cdot 9375 \\
311 \cdot 5375 \\
307 \cdot 0625 \\
302 \cdot 5125 \\
297 \cdot 8575 \\
293 \cdot 1875 \\
285 \cdot 4125 \\
283 \cdot 5625 \\
278 \cdot 6375 \\
273 \cdot 6375 \\
268 \cdot 5625 \\
263 \cdot 1125 \\
258 \cdot 1875 \\
252 \cdot 6575 \\
247 \cdot 5125 \\
212 \cdot 0625 \\
236 \cdot 5375 \\
230 \cdot 9375 \\
225 \cdot 2625 \\
219 \cdot 5125 \\
213 \cdot 6875 \\
207 \cdot 7875 \\
201 \cdot 8125 \\
195 \cdot 7625 \\
189 \cdot 6375 \\
92 \cdot 4981375 \\
90 \cdot 9390625 \\
177 \cdot 1625 \\
170 \cdot 8125 \\
161 \cdot 3875 \\
157 \cdot 8575 \\
151 \cdot 3125 \\
11 \cdot 1 \cdot 6625 \\
137 \cdot 9375 \\
131 \cdot 1375 \\
12 \cdot \cdot 2625 \\
117 \cdot 3125 \\
110 \cdot 2875 \\
103 \cdot 1875 \\
96 \cdot 0125 \\
88 \cdot 7625 \\
81 \cdot 4375 \\
74 \cdot 0375 \\
66 \cdot 5625 \\
59 \cdot 0125 \\
51 \cdot 3875 \\
43 \cdot 6575 \\
35 \cdot 9125 \\
28 \cdot 0625 \\
20 \cdot 1375 \\
12 \cdot 1375 \\
1 \cdot 0625 \\
\end{array}$ & 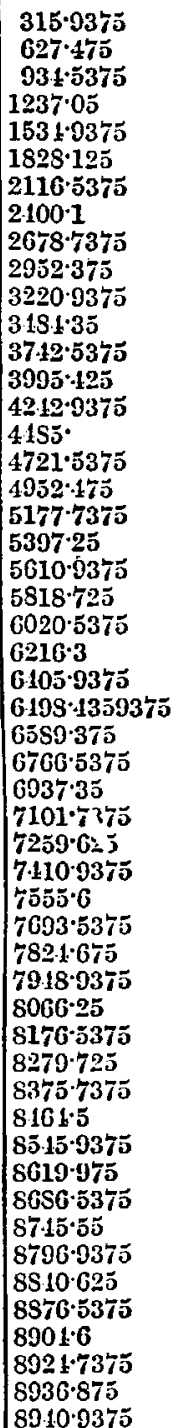 & 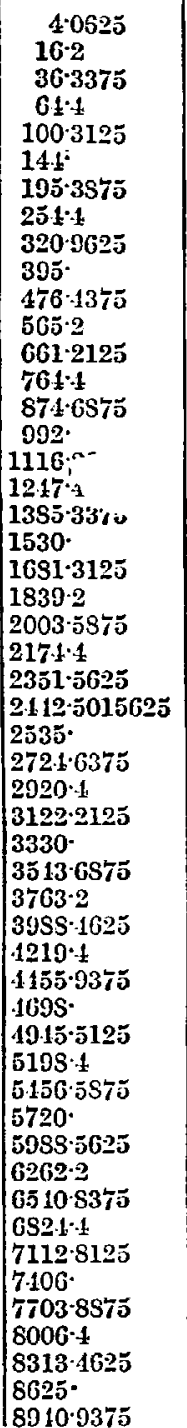 & 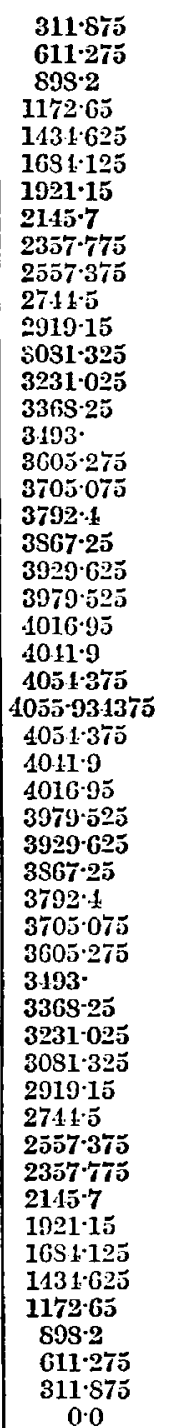 & $\begin{array}{l}311 \cdot 875 \\
299 \cdot 4 \\
286 \cdot 925 \\
27 \cdot 4 \cdot 45 \\
261 \cdot 975 \\
219 \cdot 5 \\
237 \cdot 025 \\
221 \cdot 55 \\
212 \cdot 075 \\
199 \cdot 6 \\
187 \cdot 125 \\
174 \cdot 65 \\
163 \cdot 175 \\
149 \cdot 7 \\
137 \cdot 225 \\
121 \cdot 75 \\
112 \cdot 275 \\
99 \cdot 8 \\
87 \cdot 325 \\
74 \cdot 85 \\
62 \cdot 375 \\
49 \cdot 9 \\
37 \cdot 425 \\
21 \cdot 95 \\
12 \cdot 175 \\
1 \cdot 559375 \\
1 \cdot 559375 \\
12 \cdot 475 \\
21 \cdot 95 \\
37 \cdot 425 \\
49 \cdot 9 \\
62 \cdot 375 \\
74 \cdot 85 \\
87 \cdot 325 \\
99 \cdot 8 \\
112 \cdot 275 \\
121 \cdot 75 \\
137 \cdot 225 \\
149 \cdot 7 \\
162 \cdot 175 \\
17 \cdot 1 \cdot 65 \\
187 \cdot 125 \\
199 \cdot 6 \\
212 \cdot 075 \\
221 \cdot 55 \\
237 \cdot 025 \\
219 \cdot 5 \\
261 \cdot 975 \\
27 \cdot 4 \cdot 15 \\
296 \cdot 925 \\
299 \cdot 4 \\
311 \cdot 875 \\
\end{array}$ \\
\hline
\end{tabular}


TIOLE 13.

To Show the Trajectory for Telocity 636.1385 Fect per Sccond.

\begin{tabular}{|c|c|c|c|c|c|c|c|}
\hline ceconds. & Fo & & & Sine. & Eleration. & & \\
\hline \multirow{6}{*}{$\begin{array}{l}0 \cdot 5 \\
1 \\
1 \cdot 5 \\
2 \\
2 \cdot 5 \\
3 \\
3 \cdot 5 \\
4 \\
4 \cdot 5 \\
5 \\
5 \cdot 5 \\
6 \\
6 \cdot 5 \\
7 \\
7 \cdot 5 \\
8 \\
8 \cdot 5 \\
9 \\
9 \cdot 5 \\
10 \\
10 \cdot 5 \\
11 \\
11 \cdot 5 \\
12 \\
12 \cdot 5 \\
13 \\
13 \cdot 5 \\
14 \\
14 \cdot 5 \\
15 \\
15 \cdot 5 \\
16 \\
16 \cdot 5 \\
17 \\
17 \cdot 5 \\
18 \\
18 \cdot 5 \\
19 \\
19 \cdot 5 \\
20 \\
20 \cdot 5 \\
21 \\
21 \cdot 5 \\
22 \\
22 \cdot 5 \\
23 \\
23 \cdot 5 \\
21 \cdot 5 \\
21 \cdot 5 \\
25\end{array}$} & \multirow{6}{*}{ 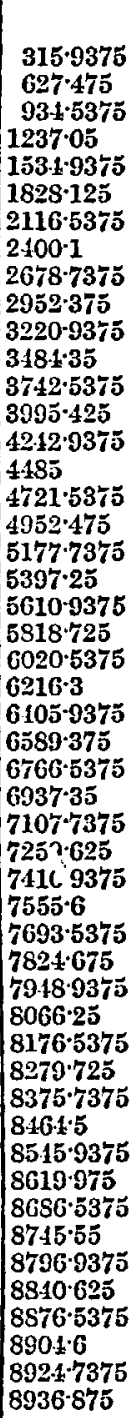 } & \multirow{6}{*}{ 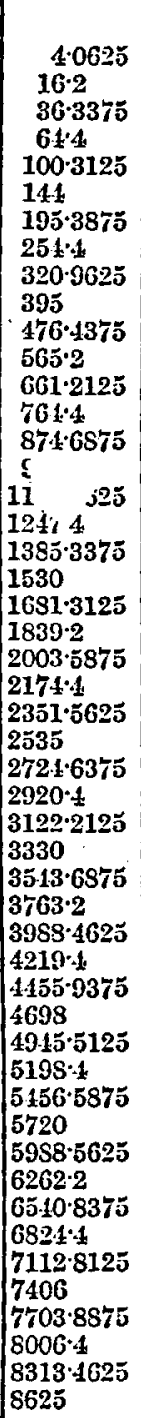 } & \multirow{6}{*}{\begin{tabular}{|l|}
$105 \cdot 3$ \\
209 \\
308 \\
$411 \cdot 8$ \\
$510 \cdot 3$ \\
$598 \cdot$ \\
$702 \cdot 5$ \\
$795 \cdot 5$ \\
$886 \cdot 5$ \\
973 \\
$1061 \cdot 8$ \\
1146 \\
1228 \\
1307 \\
1358 \\
1458 \\
$1529 \cdot 2$ \\
$1597 \cdot 6$ \\
$1656 \cdot 8$ \\
$1725 \cdot 3$ \\
$1784 \cdot 3$ \\
1810 \\
$1892 \cdot 4$ \\
1941 \\
1956 \\
$2027 \cdot 4$ \\
$2061 \cdot 6$ \\
$2097 \cdot 6$ \\
$2128 \cdot 4$ \\
$2150 \cdot$ \\
$2169 \cdot 6$ \\
2181 \\
2193 \\
$2196 \cdot 5$ \\
$219 \cdot 5$ \\
2186 \\
2169 \\
2148 \\
2118 \\
2080 \\
2032 \\
1974 \\
1905 \\
1823 \\
$1725 \cdot 5$ \\
16093 \\
$1470 \cdot 4$ \\
1299 \\
1082 \\
$780 \cdot 1$
\end{tabular}} & \multirow{6}{*}{ 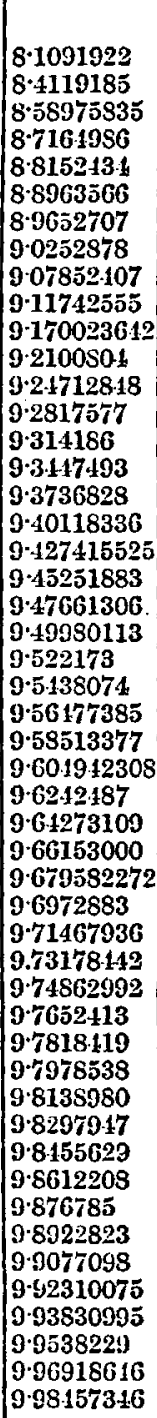 } & \multicolumn{2}{|c|}{\begin{tabular}{lcc}
0 &, & \multicolumn{1}{c}{} \\
0 & 41 & 12 \\
1 & 28 & 45 \\
2 & 13 & 40 \\
2 & 59 & \\
3 & 45 & \\
4 & 31 & \\
5 & 17 & 40 \\
6 & 05 &
\end{tabular}} & 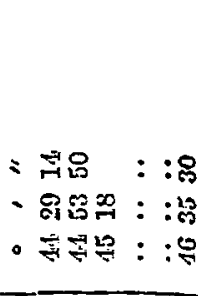 \\
\hline & & & & & 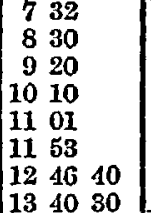 & 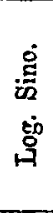 & 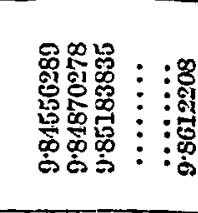 \\
\hline & & & & & $\begin{array}{lll}14 & 35 & 15 \\
15 & 31 & 08 \\
16 & 28 \\
17 & 26 \\
18 & 25 \\
19 & 26\end{array}$ & 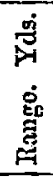 & 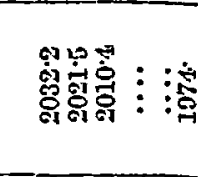 \\
\hline & & & & & $\mid \begin{array}{lll}20 & 28 & 15 \\
21 & 32 & 12 \\
22 & 37 & \\
23 & 45 & \\
24 & 53 & 40 \\
26 & 03 & 30 \\
27 & 18 & \\
28 & 34 & \end{array}$ & 节 & 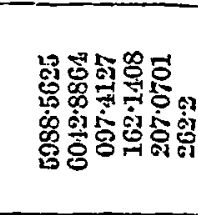 \\
\hline & & & & & $\begin{array}{l}3 \\
3 \\
3 \\
3 \\
3\end{array}$ & 总 & 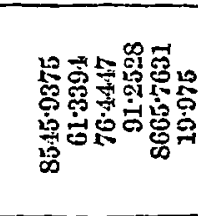 \\
\hline & & & & & $\begin{array}{l}4 \\
4 \\
4 \\
4 \\
5\end{array}$ & & \\
\hline
\end{tabular}

Great Mlalfron, 10th dugut, 1864. 


\section{APreNeIX C.}

$\Lambda$ ball, suffered to fall freely from a state of rest, describes a space of $12644 \cdot 4$ feet in the last $25 \cdot 5$ seconds of the time of falling.

To determine the height from which it fell and the velocity acquired by the fall.

1st. The fall for 31.7 seconds is $31 \cdot 7^{2} \times 13.13=1319 t \cdot 2057$

$$
\text { Differences } \frac{6 \cdot 2}{25 \cdot 5} \quad " \quad \frac{6 \cdot 2^{3}}{25 \cdot 5} \times \frac{15 \cdot 68}{2 \cdot 55}, \frac{602 \cdot 7392}{12591 \cdot 4665}
$$

which is $\mathbf{5 3 \cdot 9}$ feet short.

2nd. The fall for $31 \cdot 8$

$\frac{5 \cdot 3}{25 \cdot 5} \quad \because \quad \frac{6 \cdot 3^{2}}{25 \cdot 5} \times \frac{15 \cdot 67}{2 \cdot 55}, \frac{621 \cdot 9123}{12645 \cdot 5265}$

which is 1.1266 fect orer.

3rd. The fall for $31 \cdot 79$

$$
\begin{aligned}
& \text { " } 31 \cdot 79^{2} \times 13 \cdot 121=13260 \cdot 1363961 \\
& \overline{25 \cdot 5}, \overline{2 \cdot 55}=\overline{12610 \cdot 127385}
\end{aligned}
$$

which is $4 \cdot 27$ fect short.

$$
\overline{25 \cdot 5} \quad
$$

4th. The fall for $31.798 \quad 31.798^{2} \times 13.1202=13266.0022110108$

$$
\frac{6.298}{25} \quad \frac{6.298^{2}}{25} \times 15.6702=\frac{621.4565765408}{12544.4456345}
$$

which is only two-thirds of an inch more than the magnitude of $\Lambda \mathrm{B}$.

The final velocity represented by a fall of 31.708 seconds' duration is thus found:

the fall in $31.8 \mathrm{scconds}$, is $31.8^{2} \times 13.12=13267^{-4688}$

$$
31.798 \text { " } 31.798^{2} \times 13 \cdot 1202=13266 \cdot 0022110408
$$

the differences are $\quad 0.002,0.0002, \quad 1.46658895$ which indicates a velocity of 733.2944796 feet, say 733.3 feet per second. 


\section{APPENDIX.}

Table D.

Initial Telocity 733.3 Feet.

Range at $45^{\circ}=2980.3125$ Yards in 25.5 Seconds.

\begin{tabular}{|c|c|c|c|c|c|c|}
\hline $\begin{array}{c}\text { Secs. } \\
\text { of } \\
\text { Time. }\end{array}$ & $\begin{array}{c}\text { Graduation of } \\
\text { the Ascent. } \\
\text { AB. }\end{array}$ & $\begin{array}{c}\text { Groduation of } \\
\text { the Descent. } \\
\text { BG. }\end{array}$ & $\begin{array}{l}\text { Eleration } \\
90^{\circ} \\
A B .-B G .\end{array}$ & $\frac{A G=}{\sqrt{A B^{2} \cdot B G^{2}}}$ & $\begin{array}{l}\text { Log. Sine. } \\
\angle \mathbf{B} A G \text {. }\end{array}$ & $\angle \mathbf{B A G}$ \\
\hline & & & & & & 0.11 \\
\hline 1 & $726 \cdot 1-15$ & $16 \cdot 2$ & $719 \cdot 218$ & $7 \geq 6 \cdot 2$ & 8.3183105 & 1164 \\
\hline 2 & & 61 & 137 & 143 & & 233 \\
\hline 3 & 2136 & 141 & $1992-381$ & $2131 \cdot 6$ & 3832 & 352 \\
\hline 4 & 2 & 25 & 256 & $2 \mathrm{~s} 07$ & $8 \cdot 9$ & 511 \\
\hline 5 & & & 309 & $3462 \cdot 5$ & 0.0 & 630 \\
\hline 6 & 41 & 56 & $3569 \cdot 688$ & 1006 & $9 \cdot 1357385$ & 75120 \\
\hline 7 & 47 & 76 & 400 & 4700 & $9 \cdot 2$ & 9133 \\
\hline $\mathbf{8}$ & & 99 & 430 & 5396 & & 1035 \\
\hline 9 & 5 & 121 & 4731 & $5817 \cdot 75$ & 3045 & 120230 \\
\hline 1.1 & 6 & & 502 & ד3 & & 1327 \\
\hline 11 & & & 527 & 6St & & 1458 \\
\hline 12 & & 2 & 547 & 733 & 317 & 163020 \\
\hline 13 & & & 56 & 776 & $9 \cdot 4$ & 18013 \\
\hline 14 & & & 57 & 815 & & 1941 \\
\hline 15 & & & & 8 & $9 \cdot 5$ & 21214 \\
\hline 16 & 95 & & 38 & 882 & 8.59 & 2306 \\
\hline 17 & 100 & & & 908 & & 2.154 \\
\hline 18 & & & & 930 & & 2647 \\
\hline 19 & & & & 917 & $9 \cdot 6$ & 28453 \\
\hline 20 & 1 & $5 ?$ & & & & $\begin{array}{lll}30 & 49 & 30\end{array}$ \\
\hline 21 & & & & 963 & & $\begin{array}{llll}33 & 01 & 4\end{array}$ \\
\hline 22 & & 6 & 736 & 962 & & 3521 \\
\hline 23 & & & 311 & 953 & $9 \cdot 7$ & 3750 \\
\hline 21 & & & & 936 & & 4031 \\
\hline 25 & & 862 & & 911 & & $\begin{array}{lll}43 & 26 & 30\end{array}$ \\
\hline 26 & & & & 874 & 5410 & 463315 \\
\hline 27 & 12902.076 & & & 8253 & 9.8 & 50123 \\
\hline 28 & $7 \cdot 58.4$ & 10581 & 2153.581 & 7613 & $9 \cdot 00$ & 5116 \\
\hline 29 & & $11269 \cdot 1$ & $1872 \cdot 472$ & Gto1 & $9 \cdot 93$ & $\begin{array}{llll}59 & 02 & 30\end{array}$ \\
\hline 30 & 13215 & 1197 & 12.1 & 560 & $9 \cdot 95$ & 615530 \\
\hline 31 & $13257 \cdot 088$ & 12685.2 & $\mathbf{5 7 1} \cdot 883$ & $3851 \cdot 7$ & $9 \cdot 9$ & $7306 \quad 30$ \\
\hline & $13267 \cdot 2653$ & $13267 \cdot 1658$ & & & $10 \cdot 0000000$ & 90 \\
\hline
\end{tabular}

APPEXdix E.

The French dide-Arémoire gives a range at $45^{\circ}$ elevation of 3261 metres, with initial velocity $239^{\mathrm{m}}$.

1. This range is 10690.341 English feet at $45^{\circ}$, the rertical descent, or fall by gravity is therefore also $10699 \cdot 3.1$, whence we deduce the time of flight, 28.17 seconds, for $28 \cdot 17^{2} \times 13 \cdot 483=10699 \cdot 4108187$ feet. 
2. The oblique ascent in that time is $10699 \cdot 34 \sqrt{2}$ or $15131 \cdot 15$ and the mean velocity of this ascent is $\frac{15131 \cdot 15}{28 \cdot 17}=\frac{\mathrm{R}}{\mathrm{t}}=537$ fect.

3. The time in which a falling body acquires a velocity of 537 fect is 20.2 seconds, if we add to this one-half of the time of flight, $20 \cdot 2+14 \cdot 085=3 \cdot \cdot 285$ we shall have an approxination to the possible time of flight of this ball's initial velocity, therefore an approximate indication of the initial velocity.

4. Jiore exactly o find that the fall by gravity in 35.32 seconds is $35.32^{2} \times 12 \cdot 768=15028 \cdot 1106132$ and in $7 \cdot 15 \quad 7 \cdot 15^{2} \times 15.585=796.7430625$ so that in $\overline{28 \cdot 17}$ we hare $\overline{28 \cdot 17}, \frac{1}{2 \cdot 817} \overline{15131 \cdot 3675807}$ almost exactly the magnitude and duration of the oblique ascent.

5. The velocity which a ball acquires by a fall of 35.32 scconds is easily found--

From $35 \cdot 32^{2} \times 12 \cdot 768=15928 \cdot 1106.432$

Take $35 \cdot 31^{2} \times 12 \cdot 769=15920 \cdot 3394009$, the differences $0.01,0.001$, and $7 \cdot 7712423$ indicate $a$ relocity of $777 \cdot 12423$ feet which is 236.86318 metres, differing from the French 239 motres by $2^{\mathrm{m}} \cdot 13682$.

APrEDDIX F.

Description of an Instrument Constructed to Show the Trajectory of a Ball from given Elevation and Range, together vith its Initial Velocity and Force of Striking.

The instrument consists of three straight bars and a set of metal rods; the three bars form a right-angled triangle, upon the lyppothenuse of which wo hang the metal rods to denote the fall by gravity in successive seconds, the trajectory is then visible; the initial relocity is printed on the hypothenuse, and the final relocity, multiplied by the weight of the ball, is the force of the stroke.

The three straiglut bars represent:-

I. The oblique ascent in the time of flight, $t$. .

II. The vertical descent in the time of flight, $t$.

III. The horizontal range resulting from the two simultaneous motions of ascent and descent.

The two bars which represent the ascent and the descent are joined by a hinge, forming the apex of the right-angled triangle; these two bars are graduated exactly alike. Upon the vertical bar the graduation represents the fall by gravity, as modified by the resistance of the atmosphere; upon the front of the rertical bar are printed the figures $1,2,3$, and so onwards to denote the time; and on the side of it, the figures $16^{\circ} 1,64^{\circ} 4,144$, and so on to denote the fall by gravity. Upon the oblique bar is printed the velocity which a ball would acquire by falling vertically through a space equal to the distance from the apex of the triangle to each point of the graduation. The horizontal 2 I. 2 
bar is graduated by merely marking off equal spaces to represent successively 100, 200, 300 yards' range. $\Lambda$ t one end of the horizontal bar is a pentagraph joint, fixed; through the side tube of this passes the bar of oblique ascent; this side tube represents the gun. Upon the horizontal bar is a moreable pentagraph joint; through the side tube of this passes the bar of rertical descent.

We now proceed to show how to use the instrument. Set the oblique bar to the required angle with the horizontal bar, and run it out until the rertical bar intersects the horizontal bar at the required distance, the given range, you hare now the triangle, within which is to be inscribed the trajectory. Read the time of flight upon the rertical bar, and select from the metal rods all those marked for less. time than this time of flight, and one more, upon which you mark the exact length of the vertical bar. Upon the third mark of graduation of the oblique bar, hang the metal rod marked 3, upon the next that marked 4, and so on, till all are hanging from the oblique bar, when it will be seen that the last fer hang below the horizontai bar, and the last comes short of the giren range. Now run out the bar of oblique ascent one step of the graduation marked upon it, transferring each of tho pendulums one step in succession, kecping the eleration the same; move the vertical bar further from the gun, increasing its length at the same time; this bar ceases now to be of any use except as a pillar to support the bar of obliquo ascent with all its pendulums. If the longest pendulum still shows below the horizontal bar, the oblique escent must again be run out, and all the pendulums shifted, till the mark upon tho longest pendulum as stated above exactly coincides with the giren range of the ball, then the trajectory is shown, and the initial relocity read off. 


\section{APrexdix G. SHoebUnTstss, Noteyren 2 th, 185 t.}

10.inch IIoritzer of $125 \mathrm{cut}$. Shot $140 \mathrm{lba}$. Charge $16 \mathrm{lba}, \frac{10}{1+0}=0.1112557142857^{\circ}$ Eleration $30^{\circ}$. Range 4,850 yards $=14,550$ feet. Oblique Aseent 16,800.8 feet. Vertical Descent 8100\%. Time 21.64. Initial Velocity, 836.8.

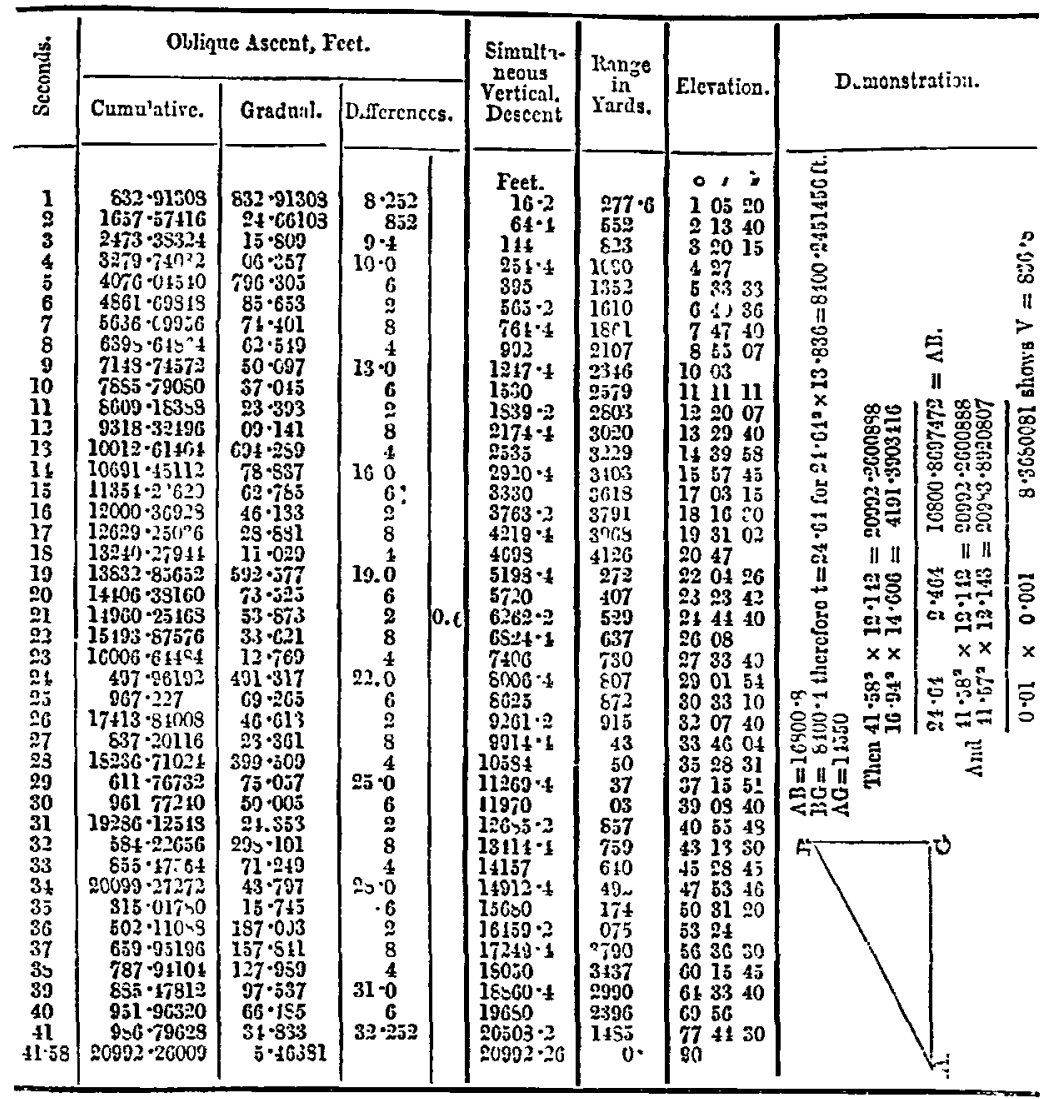

JIr. Ouver BrRYe: When great minds conspire to perpetuato a fallacy, it has always been a difficult matter to clear that fallacy away. I know of no subject capable of being submitted to mathematical inrestigation that has receired a greater amount of fallacious treatment, and that too, by great minds, than the motion of projectiles. Initial relocities hare been little more than guessed at, the resistance of the air orerrated, and the foree of grarity mis-stated. The system introduced by Gen. Anstruther, which is practical, and easily applied, must gire correct results within the range of his experiments, without offering any specinl theory about initial relocities, the resistance of the air, or the force of grarity. Indeed in bis system are collected all those elements. Let us examine the theories put forward with respect to the resistance of the atmosphere to the motion of a ball passing through it. The resistance of a fluid to the motion of a body is said to rary as the square of the relocity; the hypothesis 
upon which this law rests may be thus considered; the fluid displaced must late the same motion giren to it as that of the moring body, hence on this supposition, the units of work destrojed by the fuid will bo equal to the accumulated work in the fiuid.

Fig. 1.

Telocity $=7$ fect a second.

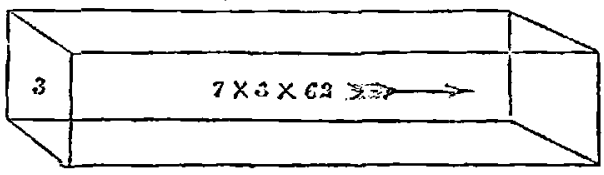

in the displacement will be-
For cxample, let the crosssection of the body perpendich. lar to the direction in which the body mores $=3$ sq. ft. the weight of a cubic foot of the nuid $=62 \mathrm{lbz}$, and the relocity of the sody $7 \mathrm{ft}$. a second.

The reight of the fluid mored at $=$ relocity of $7 \mathrm{ft}$. a second $=7 \times 3 \times 62 \mathrm{lbs}$.

The units of work expended

$$
\frac{7^{2} \times 7 \times 3 \times 62}{2 g}
$$

In which $g$ is put $=32 \frac{1}{2} ; 32 \frac{1}{2} ; 32$; \&c.; and is said to rary inversely, as the equare of the distance from the centro of the earth.

Then the body in moring through $7 \mathrm{ft}$. destrogs-

$$
7 \times \frac{7^{2} \times 3 \times 62}{61} \text { units of work. }
$$

If $T$ be the resistance of tho fluid in pounds, tho units of work destroyed will also bo represented by $\mathbf{T} \times \mathbf{7}$;

$$
\begin{aligned}
\therefore \mathrm{T} \times 7 & =7 \times \frac{7^{2} \times 3 \times 62}{61} \\
\text { or } \mathrm{T} & =\frac{7^{2} \times 3 \times 62}{6 t}
\end{aligned}
$$

Hence it is concluded that the resistance increases with the square of the relocit, as rell as with the area of the cross section of the body presented to the fluid. It is casily perceived, especially with high relocities, that this law is not strictly true, and rery far from the truth winen tho motion takes place in air. It has been found from experiments on railways, that the resistance of the atmosphere to the motion of the train, depends chielly on the length of the train, and not upon the frontage of the carriages. The resistance resembles more that of friction than the moring of a long paralleloped of the fluid in which the body mores.

Taking this latter viow of the motion of a ball through the atmosphero from one giren point to another, the units of work will always be the same, whaterer may be the form of the curre described.

Let W, Fig. 2, be a body mored through the air, then by the resolution of pressures, the pressure of $\mathrm{W}$, perpendicular to the tangent $=\mathrm{W} \operatorname{Cos} a$.

$$
\therefore \text { The resistance of friction }=f \mathrm{~W} \operatorname{Cos} a \text {, }
$$

putting $f$ for the coeflicient of the friction of the air on the ball. Ilence the total work on the plane $a \beta=z f \mathrm{~W} \operatorname{Cos} a+W_{y}$; but $z \cos \alpha=x$,

$$
\therefore \text { The work on each plano }=f \mathrm{~W} x+\mathrm{W} y \text {. }
$$

This expression being independent of the inclination of the plane. It points out the work employed to moro the body orer the horizontal distanco $\alpha \gamma$, added to the work duo to the grarity in elerating the body the rertical space $\beta \gamma$. Since a curre mas be supposed made up of an intinite number of straight lines, therefore the work upon the whole curre will be equal to the work done upon the horizontal projection $\perp B$, added to tho work done in opposition to grapity in raising the body from $\mathrm{BS}$ to $\mathrm{C}$, no. matter what form be given to the curre $\Lambda$ W W W C. This demonstration shows 
that the way in which General Anstruther has treated the resistance of the air to be the most rational yet proposed. In the next place let us examine the manner in which the value of $g$, representing the foree of grarity, has been estimated.

FIG. 2.

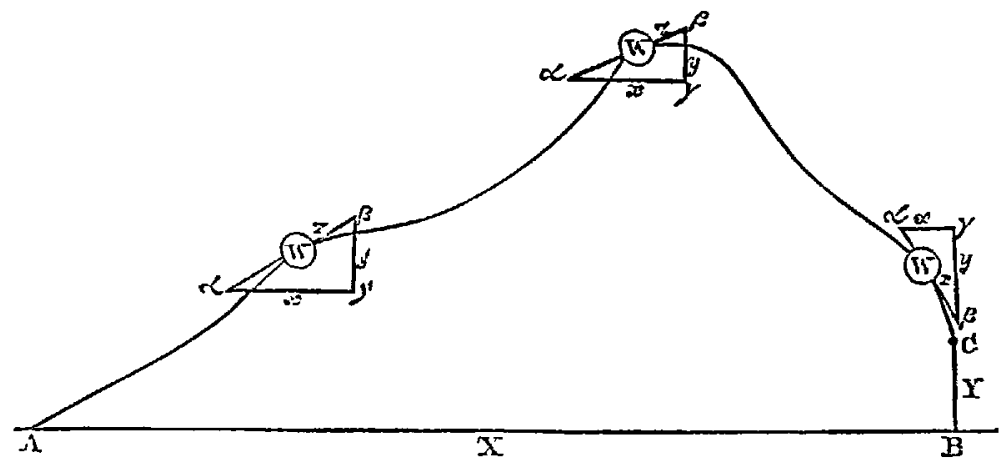

Iet $\mathrm{r}=\mathrm{C} \mathrm{MI}=$ radius, Fig. $3 . ; \mathrm{r}=$ the uniform relocity of $\mathrm{II}$ on the curre: $t$ $=$ the time emplojed in moring from $M I$ to $m$, or in falling from $M[$ to $p$. If $f$ be considered constant during a slrort space of time

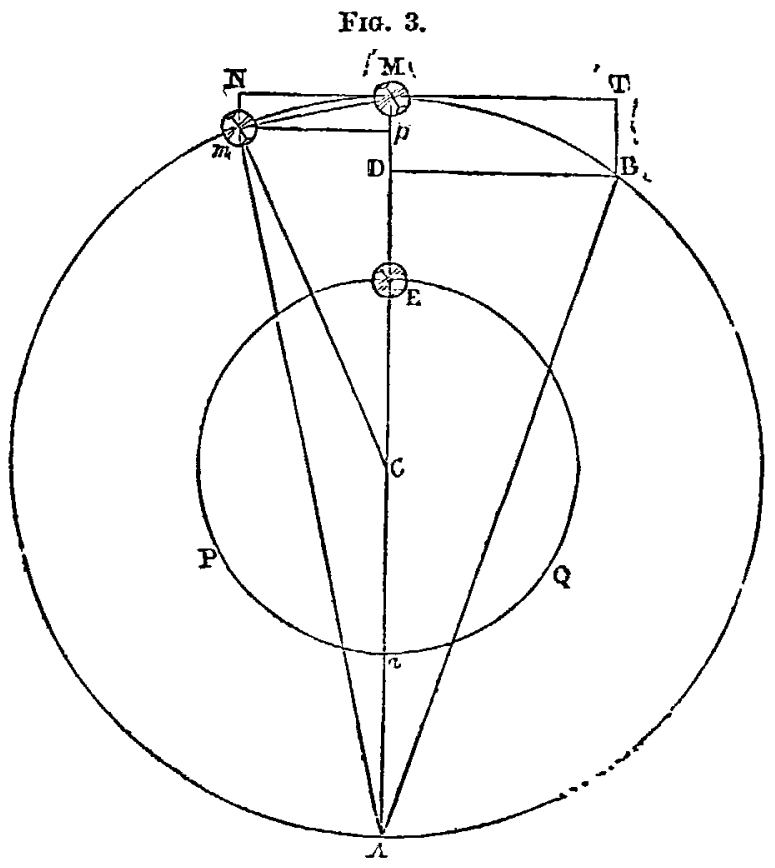




$$
\begin{aligned}
\quad \mathrm{d} t & =\mathrm{dr} \\
\therefore f \mathrm{t} & =\mathrm{v}=\frac{\mathrm{ds}}{\mathrm{dt}} \\
\therefore \mathrm{s} & =\frac{f \mathrm{t}^{2}}{2}=\mathrm{Nm}=M \mathrm{p} .
\end{aligned}
$$

$m M I=r t=$ uniform relocity $\times$ time.

Again supposo the timo so short that the are is equal to the chord, or are $m \mathrm{MI}=$ chord $\mathrm{m} \mathrm{MI}$.

$$
\begin{aligned}
& \text { Then } M \Gamma \mathrm{p} \times 3 \Gamma \mathrm{A}=\left(\text { chord } 3[\mathrm{~m})^{2}=\left(\operatorname{arc} 3[\mathrm{~m})^{2}=(\mathrm{r})^{2}\right. \text {; }\right. \\
& \text { but, } \mathrm{MP}=\frac{f \mathrm{t}^{2}}{2} \text { and } \mathrm{MIA}=2 \mathrm{r} \text {, } \\
& \therefore \operatorname{Mr} \times 2 I d=\frac{f t^{2}}{2} \times 2 r=v^{2} t^{2} \\
& \therefore f=\frac{r^{2}}{r} \text {; }
\end{aligned}
$$

If $T$ be the time of an entire rerolution, then

$$
\begin{aligned}
& \operatorname{Tr}=2 \pi x \because r^{2}=\frac{4 \pi^{2} r^{2}}{T^{2}} \\
& \text { and } f=\frac{4 \pi^{2} r}{T^{2}} ; \text { (B). }
\end{aligned}
$$

Let another body E, Fig. 3, describe the circumference of a circle $\mathbf{E} \mathbf{P}$ in the time $T_{1}$; and let $F$ represent the accelerating forec of grarity at $\mathrm{E}$. Put $\mathrm{R}=\mathrm{E} \mathrm{C}$, then, from (B)

$$
\begin{aligned}
F & =\frac{4 \pi^{2} R}{\mathrm{I}_{1}^{2}} \\
\therefore f: F & :=\frac{r^{2}}{\mathrm{~T}^{2}}: \frac{R}{\mathrm{~T}_{1}^{2}}:
\end{aligned}
$$

Now the third law established by the cxperiments of Joln Kepler ehows that the squares of the times are as the cubes of the distanees from the centre $\mathrm{C}$; hence if wo put $r^{3}$ for $T^{2}$, and $R^{3}$ for $T_{1}^{2}$, then (C) becomes

$$
f: F:: \frac{1}{r^{2}}: \frac{1}{\mathbb{R}^{2}} \quad(\mathrm{D}) \text {. }
$$

and thus it is shom by the experinents of Kepler, that the force of grarity raries inversely as the squares of the distances. Sir Isane Nenton had little to discorer in this matter when Kepler's lars aro admitted. Tho experiments at Gereral Anstruther's command are as accurato as thoso upon which the law indicated by (D) is founded. The influence of grarity on the motion of the moon round the earth, or of the carth round the sun, is then compared rith the falling of a heary bods near the carth's surface, and near the carth's surface $f$ is represented by $g$, which is said to be found by experiments. Astronomers appls a raricty of corrections to uphold (D), and the cooked up value they hare giren to $g$. When $g$ is trimmed up to suit the motions of the hearenly bodics, it is out of gear to apply it to the falling of heary bocies in air near the earth's surface. In changing tho ralue of $g$, General Anstruther is right, for his sjstem corrects the constant quantities, and secures correct results within the range of lis limiting experiments.

To find whether the resistance of the air or any other fluid medium is proportional to the square of the relocity (V) or not, and also to find whether the ralue usually given to $(g)$, the force of grarity near the surface of the earth is under or orcr-estimated.

Gcnerally $g$ is put $=31 \frac{1}{\mathfrak{b}} ; 32 \frac{1}{3} ; 32$, \&c. 
Let $\imath^{2}$ multiplied by some constant coeficient express the retarding foree; and to simplify tho inrestigation put this coeficient under the form $n^{2} \mathrm{~g}$.

Then the retarding forco will be expressed bJ-

$$
g-g^{2} t^{2} ;(I) \text {. }
$$

In this inrestigation $s$ is put for the space passed orer in the time $t$.

In general terms if $F$ be any accelerating force, $U$ the relocity, $S$ the space, and $T$ the time, the relations between these quantities are found from the tro equations-

$$
\mathrm{U}=\frac{\mathrm{d} S}{\mathrm{~d} \mathbf{I}} \text { and } \mathrm{F}=\frac{\mathrm{dU}}{\mathrm{dT}}: \text { (II). }
$$

When $T$ is climinated from these equations, then

$$
\text { UdU }=\text { FdS : (III). }
$$

Igain eliminate $\mathrm{U}$, then we liave

$$
F d T=\frac{d: S}{d T}:(I T) \text {. }
$$

Then from (I) substitute $g\left(1-u^{2} v^{3}\right)$ for $\mathrm{F}$ in (II), then,

$$
\begin{aligned}
g d t & =\frac{d v}{1-n^{2} v^{2}}:(T) . \\
\text { From (III), gds } & =\frac{r d v}{1-n^{2} v^{2}}:(T I) .
\end{aligned}
$$

When the equations (V) and (VI) are integrated and corrected, on the supposition that when $t=0 ; v=0$ and $s=0$; the resulting equations will be

$$
v=\frac{1}{n} \frac{\varepsilon^{2 g n t}-1}{\varepsilon^{2 g t}+1} \text { and } s=\frac{1}{2 g n n^{2}} \log \cdot \frac{1}{1-n^{2} \tau^{2}}
$$

Eliminato 0 and equation (VII) is obtained

$$
s=\frac{1}{n=g} \log \frac{1}{2}\left\{\varepsilon^{n g t}+\frac{1}{\varepsilon \overline{t a}^{t} t}\right\}
$$

The reduction may be effected as follows :-

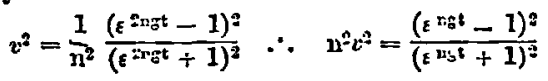

$$
\begin{aligned}
& 1-1^{2} \tau^{2}=\frac{4 \varepsilon^{2 n_{c} t}}{\left(\varepsilon^{20^{2} t}+1\right)^{2}}
\end{aligned}
$$

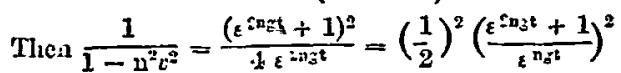

$$
\begin{aligned}
& =\left\{\frac{L}{2} \frac{\varepsilon^{\mathrm{sa} t}+1}{\varepsilon^{\mathrm{n} \tilde{s}^{t}}}\right\}^{2} \\
& =\left\{\frac{1}{2}\left(t^{p+t}+\frac{1}{t^{n} s^{t}}\right)\right\}^{2} \\
& \therefore s=\frac{1}{2 n^{2} g} \log \frac{1}{1-n^{2} x^{2}}=\frac{1}{n^{2} t} \log \frac{1}{2}\left(t^{n t}+\frac{1}{\varepsilon^{n s^{t}}}\right) \text {. } \\
& 2 \varepsilon^{\mathrm{s} \tilde{z}^{\mathrm{n} 2}}=\varepsilon^{\mathrm{E} \mathrm{n}:}+\frac{1}{\mathrm{e}^{\mathrm{n} \mathrm{B}^{\mathrm{t}}}} \text { (VIII). }
\end{aligned}
$$

Now from (VIII) the ralues of 82 and $g$ mas be found by dropping cannow shot from a balloon, at different hnomn heights, the time occupied in falling being messured. Two different ralues of $s$ and two corresponding ralues of $t$ being thus 
determincd (VIII) presents two independent equations, from which $n$ and $g$ mas bo climinated by the dual method of solring cquations. I hare but little doubt that the liberty taken by the General to change the reputed force of gravity near the surface of the earth, to meet the practical necessity, will be warranted when the ralue of $g$ and the resistance of the atmosphere are independently and aceurately determined. The foree of gravity is pulled in all directions by astronomers, to make it fit the motions of the hearenly bodies, jet after all the corrections and allowanees are made, the moon and asteroids will not obey. The practical results giren by the system of General Anstruther also show that it is right to change the initial relocitics preriously conjectured, for it is easily demonstrated that the initial relocities giren, both by the ballistic pendulum and the pendulum of Niarez, are erroneous. These instruments may be emplojed to indicate any conjectured initial relocity, for the time incorporated in the calculation is made to depend on a body rery much restrained, falling in air a few inches. To say the least of the process, it is rery ridiculous; the results may be corrected until the time anticipated is obtained. The ralue of $g$ in or out of air is unknown, and $J$ et it is made to tell all about the pendu. lum, and in return the pendulum is made to tell all about $g$. The General points out the crrors of other systems in bold relief, and arrires at practical results within the range of his guiding experiments, without assuming initial velocity, a particular ralue for $g$, or including any wild theory about the ronderful resistance of the atmosphere to cover shortcomings.

Captain Heati, R.N., O.B. : It is not ensy to discuss a lecture of this uature at a moment's notice, but I should like to put one or two test questions to the General. 1st. Do I understand you (addressing the General) to saj, that if a shot weighing $3 \mathrm{lbs}$, and another weighing $100 \mathrm{lbs}$, are discharged in the air at the same eleration, and with charges such that they shall both have the same range, they must then, according to your theors, hare started with the same initinl relocity?

General Arstretnel: : Ies, prorided they are spherical shot.

Captain HEATI : Sccondly, do I also understand you to uphold that if those same shot, riz., one of $3 \mathrm{lbs}$,, and onc of $100 \mathrm{lbs}$, are dropped simultaneously from a balloon tro miles high, they will both, falling through the air, reach the ground at the same moment?

General ANstrctuer: Fes.

Captain HeATI : Then I hare no more questions to ask, the answets you lare giren clearly prore to my mind that your theory is erroneous. With respect to the disbelief arowed by the gentleman who has just made remarks on the paper, in the correctness of. Mrajor Narez's instrument for measuring initial relocitica, I wisl to point out to him that if he will take the obserred initial relocities recorded in the book in his hand, and multiply them by 2 or 3 , he will find the results a little larger than the obserred ranges for a two or threo seconds time of flight, which is what those who beliere in "resistance of the air" would exI cet, and this is, I think, a rough and ready proof of the correctness of the obserred initial relocities.

$J$. ReDDIE, Esq.: Mrr. Chairman, as an old member of this Institution, and although a cirilian, I beg leare to make a few obserrations on the interesting and important subject under discussion; it being one to which I hare giren considerable attention. I regret that I hare not been able completely to master General Anstruther's system, and do not understand upon what principlo the rertical parallels in his diagrams are mode to vary in their relatire distances, and gradually to decrease from the beginning to the cnd of the trajectory. It is of course plain, that if these parallels mere cquidistant throughout, the construction would resolre itself into a parabola; than whichthough it happens to be the thcorctical path of a projectile in racuo-nothing can be further from the real path of a projectile in the air. But I am told that these parallels are diminished in distance, according to a principle, though to mo they appeared to be eo, only by a kind of rule of thumb. Of one thing, howerer, I feel perfectly certain, namely, that the deriation of projectiles so immensely from the theoretical parabolic path, is not entirely-or, indecd, to any great extent-due to the resistance of the air. This deriation, I may obserre, is so rery great, that cren Dr. Wherrell, as a Cambridge mathematician (implicitly accetiug the theoretical accuracy of the parabolic trajectory in vacuo), admits that the old trajcetorics of Robins 
and other practical gunners, are far more nearly aecurate, according to our actua cxperience whenerer a ball is fired. It is, in fact, onls when balls are fired at rery slight elerations that their trajectory hos the least resemblance to a parabolic curre; and from that fact $I$ argue,-1st. That it is not "the resistance of the air" that throws out the theory; for the air is equally present when trajectories are low as when they are high; and consequently, 2nd, that the parabolic theorg is at fault, because we don't know the real ralue of " $g$," or the true acceleratire force of a falling body. I regret that my friend MIr. Byrne has not becu able to give us a corrected ralue of $g$, or a true theory of the ratio of the accelerative force with which a body falls; though he has giren us a formula by which to discores this ratio, when furnished with a few facts as to the lime of falling from a great height,-facts which there is now no excuso for our not ascertaining. Those who adhero to tho traditional theory of the air's great resistance, ought to tell us why the air should, as it Tere, conspire (as upon their theory it does) against a body moring onwards, and not equally against its downward course, or in other directions? If "the terminal relocity of a falling body cannot exceed 419 fect per second" (as in the quotation in General Anstruther's paper), hor could the initial relocity of a ball when fired, excecd that rate? But, again, we know that there is a greater currature towards the carth in the latter part of a projectile's flight than at the beginning; from which it may be inferred that this bending towards the carth is caused by gravity having rery much more influence than the current theory gires, and the air rery much less. Instead of the ball haring it deseent retarded, it is rery clear that its domaward course must rather be liastened, torrards the cnd of its path, or its trajectory would take a different form. As the air will act equally against the ball in rising and in falling, its chicf influeuce must be against the onward path of a bods when fired obliquely; and were resistance relatively less when the relocity is greater (contrary to tho current notions), that might account to some extent for the greater currature domnards, as the onward relocity of the body becomes reduced. But, I must say, that that alone would not account for the suddenness and grentness of such currature. That, I feel certain, will be found to be due to the fact, that the accelerative force of grarity, now said to be equal to 32 feet per second, has been greatly underestimated. This ratio may be approsimately true for a fall of one or two seconds (and henee the agrecment of the theory with the actual ilight of projectiles at slight elerations); but it cannot bo the true ratio of the effect of the constant force of gravity pressing downmards, after a body begins to descend. I may observe that I think there has been some misapprehension as to current riers regarding the course of a projectile. Granting the ratio of the fall of a body in equal times to be, as $1,3,5$, 7, \&c., or as the squares of the rholo times, $1,4,9,16$, \&c., there is no error in the usual mode of constructing tho parubolic trajectory, as in racuo. This is usually done by representing tho projectile force, according to the first Jaw of motion, as equal in equal times, or as the ordinates $\triangle \mathrm{B} \mathrm{B}^{\prime} \mathrm{B}^{\prime \prime}$ in figure 1 , annexed, and the force of grarity as the abscisse \& $\mathrm{C} c^{\prime} c^{\prime \prime}$, as equal to the squares of the times. These two forces combined gire the parabola A D $d d^{\prime}$.

But there is a fallacs in this mode of treating the two forces as

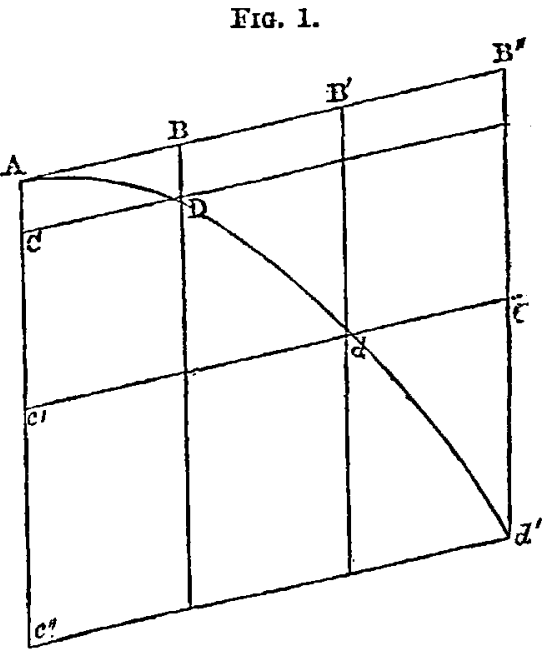


if they retained their original directions; which $I$ beg leare to point out. The grarity which is a constant force, of course continues alwars to impress new forces in one direction downwards; but the original projectile relocity becomes changed graduall 5 , from the first moment, under tlie infuence of grarity; and, by the second law of motion, its tendenes is nerer after the first moment in the direction of its original motion. A truer demonstration of the theoretical path of a projectile in zacuo, taking the current ralue of $g$, would therefore be this :-

Let A B (Fig. 2) be the original projectile relocity of a body which would fall from rest $A C$ in the time it mould describe $A B$ by its force of projection alone. Then, if gravity acted impulsirely, by the forces $A \mathrm{~B}, \mathrm{~A} C$, the body would describe $A \mathrm{D}$, and, if gravity ceased at $D$, would go on and next describe $D^{\prime} D^{\prime}$ in an equal time. If, howerer, gratity is again supposed to act at $D$, me must now suppose (according to the current methods) that it is represcnted by $D F=2 \mathrm{~A}$; and if we combine $D D^{\prime}$ with $D$ T, by these tro forees the body would next deseribe $D G$, the diagonal of the parallelogram $D D^{\prime} F G$; and a curre cutting the points $A D$ G will be a parabola. But that, I say, is a faulty demonstration, based upon the false suppositions, that grarity acts impulsirely ; which we know to be impossible. Instead, therefore, of supposing that the projectile relocity $A \mathrm{~N}$ is combined with the impulsire force $\mathrm{A} \mathbf{C}$, let tho grarity represented by $A C$ act naturally, and the body will then describe, not $A D$,

FIG. 2.

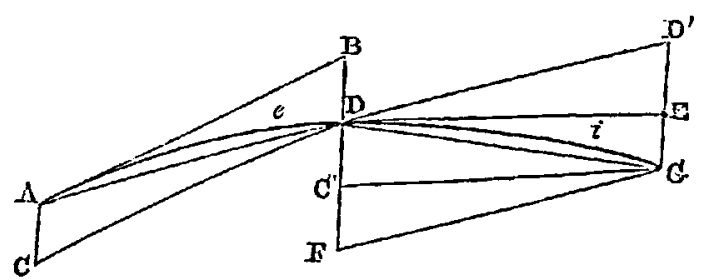

but $A e D$, in the first time; and from the point $D$, were grarity to cease, it would go on in the direction $\mathrm{D} E$ (tangent to curre $A e D$ ) and not in the direction $D^{\prime}$. If at the point $D$, then, we supposc grarity continues to act, wo must represent it by $D$ $\mathbf{C}^{\prime}=\Delta \mathrm{C}$ (for grarity $\epsilon x$ hypothesi is a constaut force, impressing cqual forces in equal times); and by $\mathrm{DE}, \mathrm{D} \mathrm{C}^{\prime}$, the body mill nest describe $\mathrm{D} i \mathrm{G}$; and the curre $\Delta e D i$ $G$ will be a parabola. It will be obserred that in this demonstration the foree of gravity is taken as equal in the tro times, and not twice as great in the next second as it was in the first. It would occupy too much time to gire a full rationale of this now, and all its results; but no one will renture to deny that $D$ E and not $D D^{\prime}$ represcnts the body's tendency after deseribing $A e D$. If so, it is clear that grarity must be taken as $\mathrm{D} \mathrm{C}^{\prime}=A \mathrm{C}^{\prime}$ only, at the point $\mathrm{D}$, or the parabolic trajectory will be thromn out. For those who rest upon authority in such matters, I may state that I hare Professor Wherell's admission, so far back as 1816, that $D \mathrm{X}$ is the proper line to represent the projectile relocity from tho point $D$, though in what are called "authorised works" on dynamics, this demonstiation has nerer been giren. It was first put forward publicly in 1862, in a small work, " Vis Inertix Ticta, or Fallacies

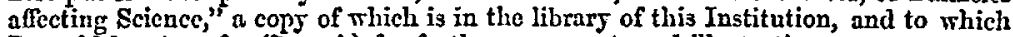
I would beg to refer (Sec. ri.) for further arguments and illustrations.

Rear-Admiral E. P. IIISTED : Would General Anstruther inform us whether his system rould require modification, if used for rifled projectiles?

General Axstnetmen: I have been unable to procure any data of rifled cannon firing whereby to test my system.

The Crimina: : You will allow me to return your thanks to Geueral Anstruthcr for his important paper; for though his riers hare been questioncd, assuning the data giren him to be correct, unless our receired trigonometry be at fault, his conclusions are undeniable; and he, and Messrs. Bjrne and Reddie, hare shown the necessity for determining the true ralue of grarity. 